Lyagaeva Ju. G., Medvedev D. A. Institute of High-Temperature Electrochemistry UB RAS, 20 Akademicheskaya street, 620990 Ekaterinburg Fax: +7(343) 374 5992; Phone: +7(343)3623263; E-mail: yulia.lyagaeva@ya.ru

\title{
Structure and transport properties of composite materials on a basis of $\mathrm{Ce}_{0.8} \mathrm{Nd}_{0.2} \mathrm{O}_{2-\delta}$ and $\mathrm{BaCe}_{0.8} \mathrm{Nd}_{0.2} \mathrm{O}_{3-\delta}{ }^{*}$
}

In the present work the synthesis of materials was carried out by one-step citrate-nitrate method. The optimal synthesis temperature of the powders was chosen on the base of TG-DSC data. Phase nature of the synthesized materials was investigated by XRD and Rietveld refinement data analyzes. The influence of the perovskite phase content in the system of $(1-x) \mathrm{Ce}_{0.8} \mathrm{Nd}_{0.2} \mathrm{O}_{2-\delta}-$ $x \mathrm{BaCe}_{0.8} \mathrm{Nd}_{0.2} \mathrm{O}_{3-\delta}(\mathrm{x}=0,0.25,0.5,0.75$ and 1$)$ on the crystallite and particle size of powders and structure properties of ceramics (relative density, porosity, grain size) were investigated. Measurements of the electrical conductivity of materials in a wide ranges of temperatures $\left(550-900{ }^{\circ} \mathrm{C}\right.$ ) and oxygen partial pressure $\left(10^{-23} \leq \mathrm{pO}_{2} / \mathrm{atm} \leq 0,21\right)$ revealed features of transport in the composite system.

*This work was done underfinancial support RFBR grant 13-03-00065, 12-03-33002) and Council for

Grants of the President of the Russian Federation (NSP-44.2012.1)

(C) Lyagaeva Ju. G., Medvedev D. A., 2015

\section{Introduction}

Materials based on barium cerate and ceria attract attention as potential electrolytes for intermediate temperature solid oxide fuel cells (IT-SOFC). A new trend in the development of electrolyte systems appeared recently: creation of composite materials such as perovskitefluorite. Composite electrolytes have the advantage compared to the reference materials: reduced electronic conductivity in reducing and oxidizing atmospheres(1), thermodynamic stability in reducing environments and $\mathrm{CO}_{2}$ and $\mathrm{H}_{2} \mathrm{O}$-containing atmospheres(2). Relatively equal values of thermal coefficients of linear expansion (CTE)-of oxides based on $\mathrm{CeO}_{2}$ and $\mathrm{BaCeO}_{3}$ also favorable for their joint use as composites(3).

The purpose of this paper is to i) synthesize and study the peculiarities of obtaining previously non-researched composites $\quad(1-x) \quad \mathrm{Ce}_{0.8} \mathrm{Nd}_{0.2} \mathrm{O}_{2-\delta}-$ $x \mathrm{BaCe}_{0.8} \mathrm{Nd}_{0.2} \mathrm{O}_{3-\delta}(x=0,0.25,0.5,0.75$ and 1) and ii) study their mechanothermal, electrical and electrochemical properties. 


\section{Results and Discussion}

In this paper we obtain the materials by the one-step citrate-nitrate method. Based on TGA-DSC analysis and mass spectroscopy it was indicated that the mass of powders stops changing at $1150{ }^{\circ} \mathrm{C}$ (see Fig. 1). Since the TGA was carried out in the dynamic mode, the materials synthesis temperatures have been slightly lowered to $1100{ }^{\circ} \mathrm{C}$ with exposure to these conditions for $3 \mathrm{~h}$.

XRF results for the synthesized powders (1-x) $\quad \mathrm{Ce}_{0.8} \mathrm{Nd}_{0.2} \mathrm{O}_{2-\delta}-$ $x \mathrm{BaCe}_{0.8} \mathrm{Nd}_{0.2} \mathrm{O}_{3-\delta}$ are shown in Fig. 2 For materials $\mathrm{Ce}_{0.8} \mathrm{Nd}_{0.2} \mathrm{O}_{2-\delta}$ and $\mathrm{BaCe}_{0.8} \mathrm{Nd}_{0.2} \mathrm{O}_{3-\delta}$ on X-ray reflections only related to the phases of fluorite (Fm3m) and perovskite (orthorhombic distortion, Pmcn), respectively, are present. Composite materials according to XRF are

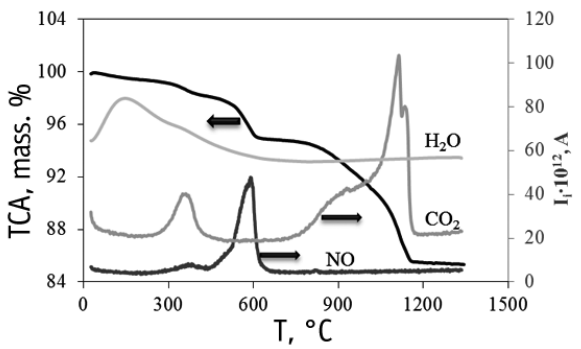

Fig. 1. TGA and the ion current to the powder $\mathrm{BaCe}_{0.8} \mathrm{Nd}_{0.2} \mathrm{O}_{3-\delta}$, prepared by citrate-nitrate method

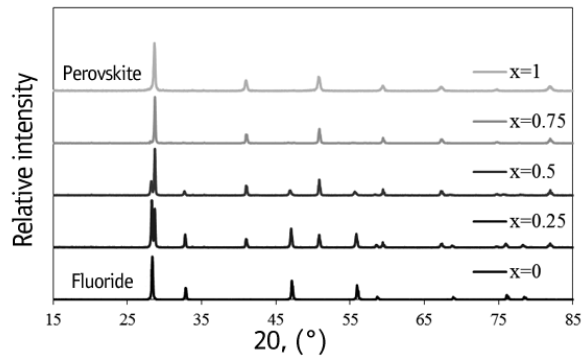

biphasic and contain no contaminants or phase interaction. However, it should be noted that the composition with $\mathrm{x}=0.75$ intensity of reflections corresponding to fluorite phase, is small compared to the expected level. This may be due to the partial dissolution of fluorite phase in perovskite. Indeed, for the interval $0.75<\mathrm{h} \leq 1$ (see Fig. 2) radiographs recorded only reflections corresponding to the isostructural phase of orthorhombic $\mathrm{BaCeO} 3$.

Refinement of the structure and the lattice parameters for the materials of the system (1-x) $\mathrm{Ce}_{0.8} \mathrm{Nd}_{0.2} \mathrm{O}_{2-\delta}-$ $x \mathrm{BaCe}_{0.8} \mathrm{Nd}_{0.2} \mathrm{O}_{3-\delta}$ was carried out by Rietveld method. The convergence of the theoretical curves with the experimental data was estimated by Bregg-and structural factors that do not exceed 0.87 and 1.02 for the cubic structure, and 1.64 and 2.10 for the orthorhombic structure, respectively. With the increase in concentration of the perovskite phase, the crystal lattice parameters of the orthorhombic structure are almost unchanged, whereas the parameters of the cubic structure are reduced. Perhaps this is connected to the assumption about the solubility of a certain amount of cerium phase in barium cerate. Part of fluorite with perovskite can form a solid

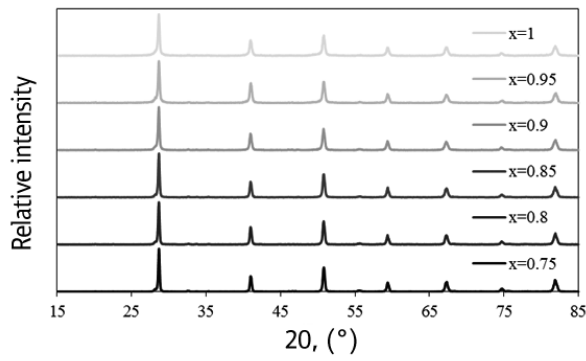

Fig. 2. Radiographs of the synthesized powders (1-x) $\mathrm{Ce}_{0.8} \mathrm{Nd}_{0.2} \mathrm{O}_{2-\delta}-x \mathrm{BaCe}_{0.8} \mathrm{Nd}_{0.2} \mathrm{O}_{3-\delta}$ at $0 \leq \mathrm{h} \leq 1$ (top) and $0.75 \leq \mathrm{h} \leq 1$ (bottom) 
solution of varied formulation with the same lattice parameters. Simultaneously with this solution fluorite phase coexists, which may be enriched with neodymium, which causes a slight increase in the lattice parameter due to the influence of the size factor.

Ceramic samples were prepared by hydrostatic pressing of the powders, followed by sintering at $1500{ }^{\circ} \mathrm{C}$ for 3 hours (see Fig. 3). All materials have a high relative density (93.2-96.5\% depending on the formulation). For a qualitative evaluation of the microstructure surface of the sintered ceramics the size of each grain was determined, based on which histograms of particle size distribution and average grain size were calculated. The average grain size does not depend significantly for composites and varies from 1.2 to 1.7 microns. In contrast, for the ceramic base $\mathrm{Ce}_{0.8} \mathrm{Nd}_{0.2} \mathrm{O}_{2-\delta}$ materials and $\mathrm{BaCe}_{0.8} \mathrm{Nd}_{0.2} \mathrm{O}_{3-\delta}$ the mean grain size

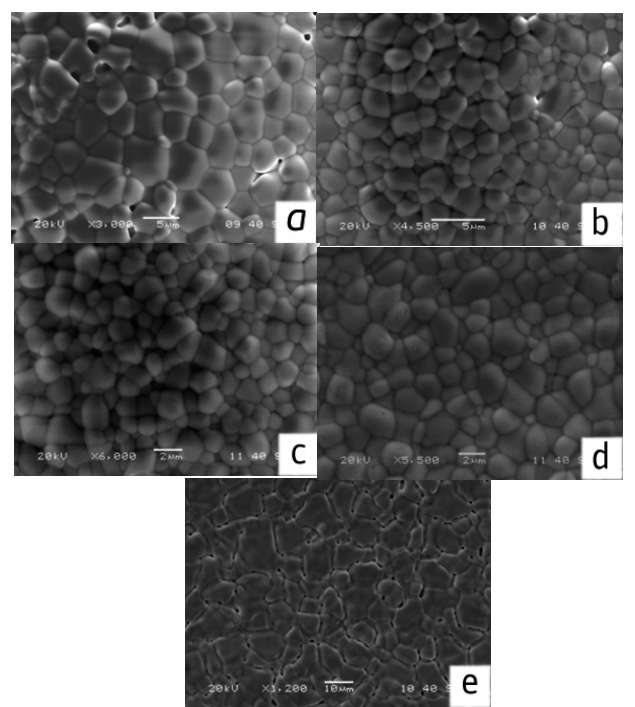

Fig. 3. Microphotograph of the surface of

(1-x) $\mathrm{Ce}_{0.8} \mathrm{Nd}_{0.2} \mathrm{O}_{2}-x \mathrm{BaCe}_{0.8} \mathrm{Nd}_{0.2} \mathrm{O}_{3-\delta}$ : $x=0$ (a), $x=0.25$ (b), $x=0.5$ (c), $x=0.75$ (d), $x=1(\mathrm{e})$ is increased to 3.7 and to 7.8 microns, respectively.

The temperature dependence of the conductivity of $(1-x) \quad \mathrm{Ce}_{0.8} \mathrm{Nd}_{0.2} \mathrm{O}_{2-\delta}-$ $x \mathrm{BaCe}_{0.8} \mathrm{Nd}_{0.2} \mathrm{O}_{3-\delta}$ materials is shown in Fig. 4. It shows that the total conductivity of the composite material in a wet air is lower as compared to the basic oxides. A similar trend was observed for composite systems of $(100-x)$ $\mathrm{Ce}_{0.8} \mathrm{Y}_{0.2} \mathrm{O}_{2-\delta}-\mathrm{BaCe}_{0.7} \mathrm{Zr}_{0.1} \mathrm{Y}_{0.2} \mathrm{O}_{3-\delta}(x=0$, 20, 30, 50, 70 and $100 \mathrm{wt} . \%)$ and $4(1-x)$ $\mathrm{Ce}_{0.8} \mathrm{Gd}_{0.2} \mathrm{O}_{2-\delta}-x \mathrm{BaCe}_{0.8} \mathrm{Gd}_{0.2} \mathrm{O}_{3-\delta} \quad(x=0$, $0.2,0.3$ and 0.4 ) 1 . In the first case, low conductivity of composite materials in comparison with the base $\mathrm{Ce}_{0.8} \mathrm{Y}_{0.2} \mathrm{O}_{2-\delta}$ and $\mathrm{xBaCe}_{0.7} \mathrm{Zr}_{0.1} \mathrm{Y}_{0.2} \mathrm{O}_{3-\delta}$ is attributed by the authors to the appearance of poorly conducting phases based on Ba2YZrO6 and $\mathrm{Ba}_{2} \mathrm{ZrO}_{4}$, which appear to localize at grain boundaries and limit the process of electrotransport(4). In the second case, a low conductivity as compared to $\mathrm{Ce}_{0.8} \mathrm{Gd}_{0.2} \mathrm{O}_{2-\delta}$ and $\mathrm{BaCe}_{0.8} \mathrm{Gd}_{0.2} \mathrm{O}_{3-\delta}$ composites is associated with high contact resistance of phase(1) interface that may be implemented in this case. High contact resistance at the interface of two different sorts of grain must necessarily lead to

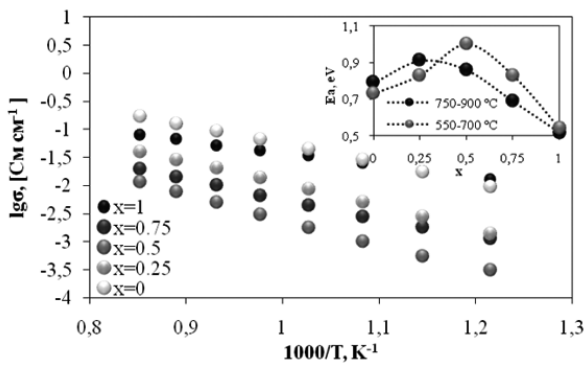

Fig. 4. Temperature dependence of the conductivity of the $(1-x) \mathrm{Ce}_{0.8} \mathrm{Nd}_{0.2} \mathrm{O}_{2-\delta}-$ $x \mathrm{BaCe}_{0.8} \mathrm{Nd}_{0.2} \mathrm{O}_{3-\delta}$ ceramics in the humid air. Inset: concentration dependence of the conductivity activation energy in the low-and high-temperature ranges 
an increase in activation energy of the overall conductivity of composites (inset in Fig. 4). Note that the sample with $x=$ 0.5 has the maximum $\mathrm{Ea}$, and at the same time has the lowest conductivity in $(1-x)$ $\mathrm{Ce}_{0.8} \mathrm{Nd}_{0.2} \mathrm{O}_{2-\delta}-x \mathrm{BaCe}_{0.8} \mathrm{Nd}_{0.2} \mathrm{O}_{3-\delta}$. Thus, the concentration dependence of the activation energy in the composite system of the growth of the perovskite phase passes through a maximum. By the level of activation energy in the low and high ranges the sample with $x=0.25$ is similar to $\mathrm{Ce}_{0.8} \mathrm{Nd}_{0.2} \mathrm{O}_{2-\delta}$. This may indicate that the conductivity of the material is controlled primarily by fluorite phase. For composites with $x=0.5$ and 0.75 , the conductivity is apparently controlled by perovskite phase. The decrease in the grain size of ceramics (or an increase in their unit area of contact) can also be considered as the cause of the overall conductivity reducing of the composite systems.

Materials conductivity has also been investigated in relation to partial pressure of oxygen $\left(\mathrm{pO}_{2}\right)$ at $600,700,800$ and $900{ }^{\circ} \mathrm{C}$. The dependences obtained were processed using the emperic equation, $\sigma_{\text {total }}=\sigma_{e, o} \cdot\left(\mathrm{pO}_{2}\right)^{-1 / 4}+\sigma_{\text {ion,o }}+\sigma_{p, o} \cdot\left(\mathrm{pO}_{2}\right)^{1 / 4}$, where $\sigma_{\text {total }}-$ total conductivity,

$\sigma_{i o n}-$ ionic conductivity (const.),

$\sigma_{p, o}-$ hole conductivity at $\mathrm{pO}_{2}=1 \mathrm{~atm}$.

The analysis results are presented in the form of concentration dependences of partial conductivities (see Fig. 5).

The concentration dependence of the ionic conductivity at $600-900{ }^{\circ} \mathrm{C}$ (Fig. 5a) corresponds to the data shown above (see Fig. 4). Comparison of Ea and total ionic conductivity (see Fig. 4) indicates predominantly ionic conductivity type as for the composite materials and for basic systems.
Electronic conductivity decreases with increasing content of the perovskite phase in the system of $(1-x) \mathrm{Ce}_{0.8} \mathrm{Nd}_{0.2} \mathrm{O}_{2-\delta}$ $x \mathrm{BaCe}_{0.8} \mathrm{Nd}_{0.2} \mathrm{O}_{3-\delta}$ to $x=0.5$ (see Fig. 6b). For samples with $x=0.75$ and 1 electronic conductivity, according to the analysis data, is less than $1 \%$ in the total. Hole conductivity appears for samples with $0.5 \leq \mathrm{h} \leq 1$ and increases with the increase of $x$ (see Fig. 6c). The activation energy of the hole and electron conductivity for
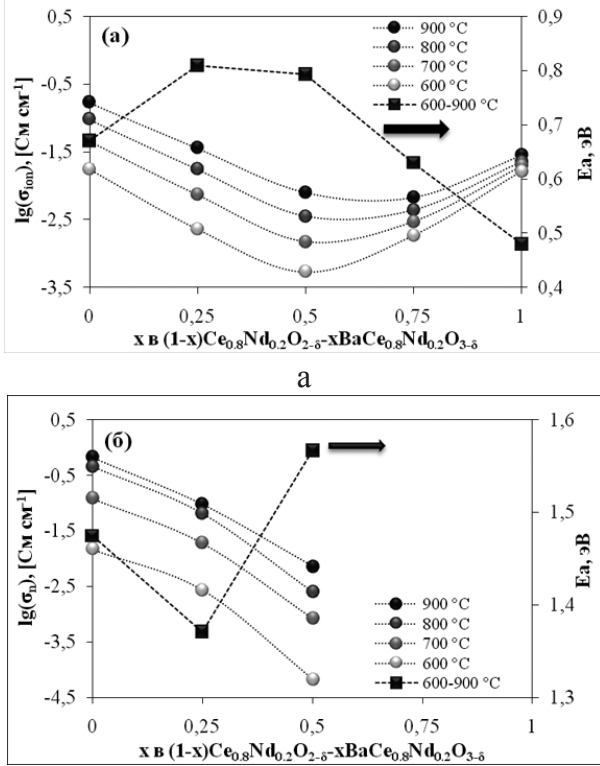

$\mathrm{b}$

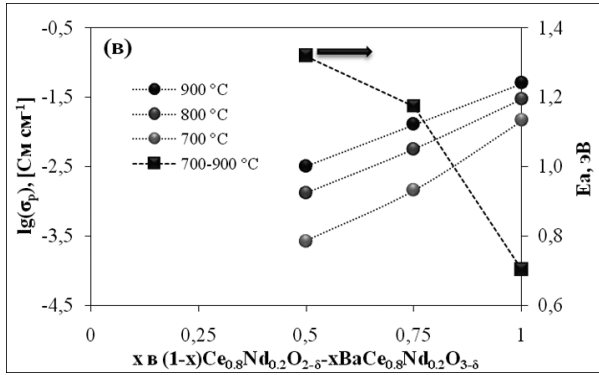

C

Fig. 5. Concentration dependence of the ion (a), electron (b) and hole (c) conductivity and activation energy for $(1-x) \mathrm{Ce}_{0.8} \mathrm{Nd}_{0.2} \mathrm{O}_{2-\delta}-$ $x \mathrm{BaCe}_{0.8} \mathrm{Nd}_{0.2} \mathrm{O}_{3-\delta}$ ceramics in the wet air 
the system «perovskite-fluorite» tend to be higher than for basic oxides as $\mathrm{Ce}_{0.8} \mathrm{Nd}_{0.2} \mathrm{O}_{2-\delta}$ and $\mathrm{BaCe}_{0.8} \mathrm{Nd}_{0.2} \mathrm{O}_{3-\delta}$, which confirms the phenomenon of blocking both the electron and hole conductivity in composites(1-3).

Despite lower ionic conductivity of composites, they show better thermodynamic and kinetic stability under longterm tests and in redox cycles (see Fig. 6 ) than basic materials. It was found that after two redox cycles at $900{ }^{\circ} \mathrm{C}$ conductivity of $\mathrm{Ce}_{0.8} \mathrm{Nd}_{0.2} \mathrm{O}_{2-\delta}$ decreases lower to $85 \%$ relatively the initial level. Possible reason for the sharp drop of conductivity is fractures in ceramics fixed by SEM, which appear due to the partial reduction/ oxidation of cerium ions (see Fig. 7). Changing of the cerium oxidation state is

\section{Conclusion}

In this paper we have obtained new composite materials based on cerium oxide and barium cerate by using citratenitrate method, and studied their transport properties. The total composite electrolyte conductivity in wet air is lower than that of the base materials due to high specific resistance and interfacial contact area of

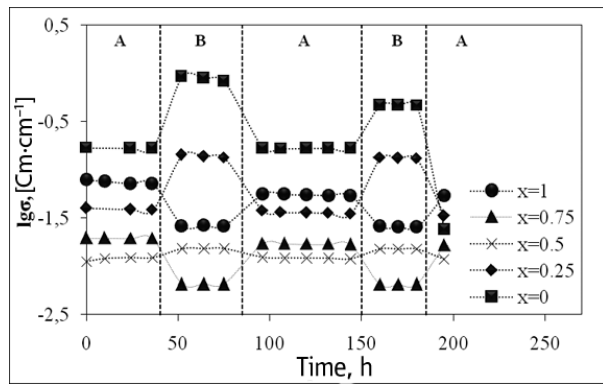

Fig. 6 Time dependence of the conductivity of $(1-x) \mathrm{Ce}_{0.8} \mathrm{Nd}_{0.2} \mathrm{O}_{2-\delta}-x \mathrm{BaCe}_{0.8} \mathrm{Nd}_{0.2} \mathrm{O}_{3-\delta}$ materials at $900{ }^{\circ} \mathrm{C}$. A corresponds to an atmosphere with $\mathrm{pO} 2=0.21 \mathrm{~atm}, \mathrm{~B}-\mathrm{pO}_{2}=$ $1 \mathrm{~atm} \cdot 10-18$ accompanied by resolution of the crystal lattice vibrations, so repetition of redox cycles leads to mechanical instability of ceramics. For $\mathrm{BaCe}_{0.8} \mathrm{Nd}_{0.2} \mathrm{O}_{3-\delta}$ material conductivity after 2 cycles is reduced to $30 \%$ relatively the initial level. Perhaps this is due to the localization of different types of point defects at the grain boundaries. During several redox cycles three-dimensional defects (microcracks) are formed along grain boundaries due to congestion and interaction of point defects. Degradation of composite materials in terms of conductivity does not exceed $15 \%$. According to SEM of ceramic samples, localized pores are noticed on the surface, which lead to an substantial decrease in conductivity.

the grains. The concentration dependence of the activation energy of conductivity for $(1-x) \mathrm{Ce}_{0.8} \mathrm{Nd}_{0.2} \mathrm{O}_{2-\delta}-x \mathrm{BaCe}_{0.8} \mathrm{Nd}_{0.2} \mathrm{O}_{3-\delta}$ has a minimum at $\mathrm{x}=0.5$. Despite the low conductivity of the composite ceramics, they are characterized by small contributions of electronic components (conductivity of n- and p-types), as well as bet-

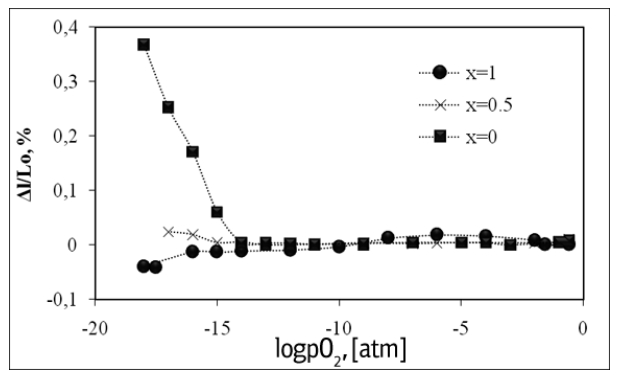

Fig. 7 Chemical expansion of ceramic $(1-x)$ $\mathrm{Ce}_{0.8} \mathrm{Nd}_{0.2} \mathrm{O}_{2-\delta}-x \mathrm{BaCe}_{0.8} \mathrm{Nd}_{0.2} \mathrm{O}_{3-\delta}$ materials at $900{ }^{\circ} \mathrm{C}$ 
ter thermodynamic and kinetic stability, which suggests that such materials are promising electrolytes for IT-SOFC.

\section{The experimental part}

Materials of formulation of $(1-x)$ erties of materials have been studied by $\mathrm{Ce}_{0.8} \mathrm{Nd}_{0.2} \mathrm{O}_{2-\delta}-x \mathrm{BaCe}_{0.8} \mathrm{Nd}_{0.2} \mathrm{O}_{3-\delta}(x=0, \quad$ RFA (DMAX-2500 RIGAKU) and SEM $0.25,0.5,0.75$ and 1 ) were prepared by (JSM-5900 LV), respectively. Matericitrate-nitrate technology which features als conductivity has been examined by 4 are presented in (3). The powders of the desired formulation were was synthesized and sintered on the basis of TGA-DSC analysis and dilatometry at $1500{ }^{\circ} \mathrm{C}$, reprobe method at constant current over a wide range of temperatures $\left(550-900{ }^{\circ} \mathrm{C}\right)$ and oxygen partial pressure (atm 10-230.21 ) using Zirconia-controller 3185. spectively. Crystal, microstructural prop-

1. Venkatasubramanian A., Copalan P., Prasanna T. Synthesis and characterization of electrolytes based on $\mathrm{BaO}-\mathrm{CeO} 2-\mathrm{GdO} 1.5$ system for Intermediate Temperature Solid Oxide Fuel Cells. International Journal of Hydrogen Energy. 2010; 35(10):45974605. doi: 10.1016/j.ijhydene.2010.02.037. [Google Scholar].

2. Sun W., Jiang Y., Wang Y., Fang S., Zhu Z., Liu W. A novel electronic current-blocked stable mixed ionic conductor for solid oxide fuel cells. Journal of Power Sources. 2011; 196(1):62-68. doi: 10.1016/j.jpowsour.2010.07.038. [Google Scholar].

3. Medvedev D., Maragou V., Pikalova E., Demin A., Tsiakaras P. Novel composite solid state electrolytes on the base of $\mathrm{BaCeO} 3$ and $\mathrm{CeO} 2$ for intermediate temperature electrochemical devices. Journal of Power Sources. 2013; 221:217. doi: 10.1016/j. jpowsour.2012.07.120. [Google Scholar].

4. Huang J., Zhang L., Wang C., Zhang P. International Journal of Hydrogen Energy. 2012; 37:13044. [Google Scholar].

5. Available from: http://zirconiaproject.wordpress.com/devices/zirconia-318/. [Google Scholar]. 
Ю. Г. Лягаева, Д. А. Медведев

ФГБУН Институт высокотемпературной электрохимии УрО РАН, 620990 ,

2. Екатеринбург, ул. Академическая, 20. Факс: (343) 374-59-92; тел.: (343) 362-32-63;

E-mail: yulia.lyagaeva@ya.ru

\section{Структура и транспортные свойства композитных материалов на основе $\mathrm{Ce}_{0,8} \mathrm{Nd}_{0,2} \mathrm{O}_{2-\delta}$ и $\mathrm{BaCe}_{0,8} \mathrm{Nd}_{0,2} \mathrm{O}_{3-\delta}{ }^{*}$}

В настоящей работе проведен синтез материалов путем одностадийного цитрат-нитратного метода. С привлечением данных ТГ-ДСК анализа установлены оптимальные температуры синтеза порошков. Фазовые особенности синтезированных материалов изучены РФА с привлечением метода Ритвелда. Установлено влияние содержания перовскитной фазы в системе $(1-x) \mathrm{Ce}_{0,8} \mathrm{Nd}_{0,2} \mathrm{O}_{2-5}-x \mathrm{BaCe}_{0.8} \mathrm{Nd}_{0,2} \mathrm{O}_{3-\delta}(x=0 ; 0,25 ; 0,5 ; 0,75$ и 1$)$ на размеры кристаллитов и частиц порошка. Исследованы керамические свойства (относительная плотность, пористость, размеры зерен) образцов, спеченных при $1500{ }^{\circ} \mathrm{C}$. Исследование электропроводности материалов в широких интервалах температур $\left(550-900{ }^{\circ} \mathrm{C}\right)$ и парциальных давлений кислорода $\left(10^{-23} \leq \mathrm{PO}_{2} /\right.$ атм $\left.\leq 0,21\right)$ позволило выявить особенности электропереноса в системе $(1-x) \mathrm{Ce}_{0,8} \mathrm{Nd}_{0,2} \mathrm{O}_{2-\delta}-\mathrm{xBaCe}_{0,8} \mathrm{Nd}_{0,2} \mathrm{O}_{3-\delta}$.

*Работа выполнена при поддержке РФФИ (№ 13-03-00065, 12-03-33002), а также Совета по грантам Президента РФ (№ СП-44.2012.1).

(C) Лягаева Ю. Г., Медведев Д. А., 2015

\section{Введение}

Материалы на основе церата бария и оксида церия привлекают повышенное внимание как потенциальные электролиты для среднетемпературных твердооксидных топливных элементов (IT-SOFC). В последнее время новой тенденцией в области развития электролитных систем является создание композитных материалов типа перовскит-флюорит. Композитные электролиты имеют преимущество по сравнению с базовыми материалами: сниженную электронную проводимость в восстановительной и окислительной атмосферах [1], термодинамическую устойчивость в восстановительных средах и $\mathrm{CO}_{2}$ и $\mathrm{H}_{2} \mathrm{O}$-содержащих атмосферах 
[2]. Близкие значения термических коэффициентов линейного расширения (ТКЛР) оксидов на основе $\mathrm{CeO}_{2}$ и $\mathrm{BaCeO}_{3}$ также благоприятны для их совместного использования в качестве композитов [3].

Целью данной работы является 1) синтез и исследование особенностей

\section{Результаты и обсуждение}

В настоящей работе получение материалов проведено путем одностадийного цитрат-нитратного метода. На основании ТГ-ДСК анализа и масс-спектроскопии установлено, что изменение массы порошков заканчивается при $1150{ }^{\circ} \mathrm{C}$ (рис. 1). Поскольку ТГ-анализ был проведен в динамическом режиме, температуры синтеза материалов были несколько снижены и

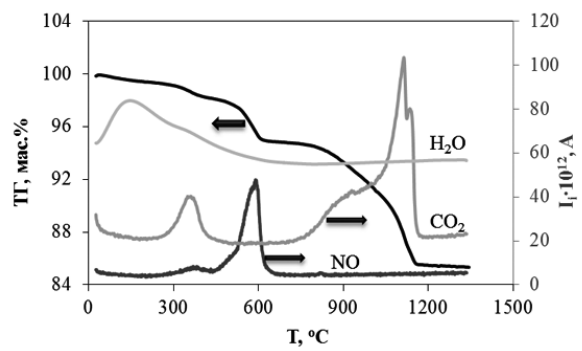

Рис. 1. ТГ и ионный ток для порошка $\mathrm{BaCe}_{0.8} \mathrm{Nd}_{0,2} \mathrm{O}_{3-\delta}$, полученного цитрат-нитратным методом

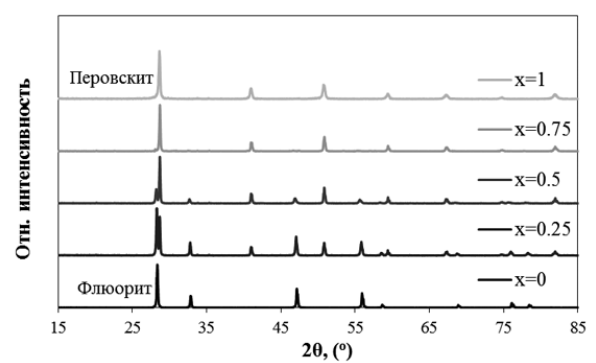

полученияранеенеизученныхкомпозитных $(1-x) \mathrm{Ce}_{0,8} \mathrm{Nd}_{0,2} \mathrm{O}_{2-\delta}-\mathrm{xBaCe}_{0,8} \mathrm{Nd}_{0,2} \mathrm{O}_{3-\delta}$ $(x=0 ; 0,25 ; 0,5 ; 0,75$ и 1$)$ материалов, и 2) исследования их механотермических, электрических и электрохимических свойств.

составляли $1100{ }^{\circ} \mathrm{C}$ с выдержкой в этих условиях в течение 3 ч.

Результаты РФА для синтезированных порошков $(1-x) \mathrm{Ce}_{0,8} \mathrm{Nd}_{0,2} \mathrm{O}_{2-\delta}$ $x \mathrm{BaCe}_{0,8} \mathrm{Nd}_{0,2} \mathrm{O}_{3-\delta}$ представлены на рис. 2. Для материалов $\mathrm{Ce}_{0,8} \mathrm{Nd}_{0,2} \mathrm{O}_{2-\delta}$ и $\mathrm{BaCe}_{0,8} \mathrm{Nd}_{0,2} \mathrm{O}_{3-\delta}$ на рентгенограммах присутствуют только рефлексы, относящиеся к фазам флюорита (Fm3m) и перовскита (орторомбическое искажение, Pmcn), соответственно. Композитные материалы, согласно РФА, являются двухфазными и не содержат примесей или фаз взаимодействия. Однако стоит отметить, что для состава $x=0,75$ интенсивность рефлексов, соответствующих фазе флюорита, мала по сравнению с ожидаемым уровнем. Это может быть связано с частичным растворением флюоритной фазы в перовскитной. Действительно, для интер-

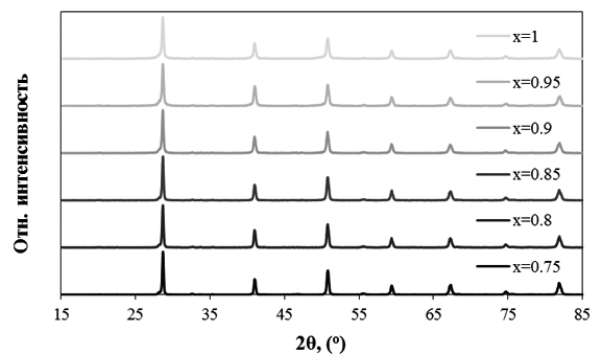

Рис. 2. Рентгенограммы синтезированных порошков $(1-x) \mathrm{Ce}_{0,8} \mathrm{Nd}_{0,2} \mathrm{O}_{2-\delta}-x \mathrm{BaCe}_{0,8} \mathrm{Nd}_{0,2} \mathrm{O}_{3-\delta}$ при: $a-0 \leq x \leq 1 ; \sigma-0,75 \leq x \leq 1$ 
вала $0,75<x \leq 1$ (рис. 2) на рентгенограммах фиксируются только рефлексы, соответствующие фазе, изоструктурной орторомбическому $\mathrm{BaCeO}_{3}$.

Уточнение структуры и параметров кристаллической решетки для материалов системы $(1-x) \mathrm{Ce}_{0,8} \mathrm{Nd}_{0,2} \mathrm{O}_{2-\delta}$ $x \mathrm{BaCe}_{0,8} \mathrm{Nd}_{0,2} \mathrm{O}_{3-\delta}$ было проведено по методу Ритвелда. Сходимость теоретических кривых с экспериментальными данными оценивалась Брэгг- и структурным факторами, которые не превышали 0,87 и 1,02 для кубической структуры и 1,64 и 2,10 для орторомбической структуры соответственно. С увеличением концентрации перовскитной фазы в системе параметры кристаллической решетки орторомбической структуры практически не изменяются, в то время как параметры кубической структуры уменьшаются. Возможно, это связано с предположением о растворимости некоторого количества цериевой фазы в церате бария. Часть флюорита с перовскитом может образовывать твердый раствор переменного состава с неизменными параметрами кристаллической решетки. Одновременно с данным раствором сосуществует флюоритная фаза, которая может быть обогащена неодимом, что и вызывает некоторое увеличение в параметрах кристаллической решетки из-за влияния размерного фактора.

Керамические образцы были получены путем гидростатического прессования порошков с последующим спеканием при $1500{ }^{\circ} \mathrm{C}$ в течение 3 ч (рис. 3). Все материалы характеризуются высокой относительной плотностью (93,2-96,5 \% в зависимости от состава). Для качественной оценки микроструктуры поверхности спеченной керамики были определены размеры каждого зерна, на основании чего построены гистограммы распределения частиц по размерам и вычислен средний размер зерен. Средний размер зерен не зависит значимо для композитных материалов и изменяется с 1,2 до 1,7 мкм. Напротив, для базовых керамических материалов $\mathrm{Ce}_{0,8} \mathrm{Nd}_{0,2} \mathrm{O}_{2-\delta}$ и $\mathrm{BaCe}_{0,8} \mathrm{Nd}_{0,2} \mathrm{O}_{3-\delta}$ средний размер зерен увеличивается до 3,7 и 7,8 мкм соответственно.

Температурные зависимости проводимости материалов $(1-x) \mathrm{Ce}_{0,8} \mathrm{Nd}_{0,2} \mathrm{O}_{2-\delta}-$ $x \mathrm{BaCe}_{0,8} \mathrm{Nd}_{0,2} \mathrm{O}_{3-\delta}$ представлены на рис. 4. Видно, что общая проводимость композитных материалов во влажном воздухе ниже по сравнению с базовыми оксидами. Аналогичная тенденция была отмечена для композитных систем состава $(100-x) \mathrm{Ce}_{0,8} \mathrm{Y}_{0,2} \mathrm{O}_{2-\delta}$ $x \mathrm{BaCe}_{0,7} \mathrm{Zr}_{0,1} \mathrm{Y}_{0,2} \mathrm{O}_{3-\delta}(x=0 ; 20 ; 30 ; 50 ; 70$ и 100 мас.\%) [4] и (1-x) $\mathrm{Ce}_{0,8} \mathrm{Gd}_{0,2} \mathrm{O}_{2-\delta}$ $x \mathrm{BaCe}_{0,8} \mathrm{Gd}_{0,2} \mathrm{O}_{3-\delta}(x=0 ; 0,2 ; 0,3$ и 0,4$)$

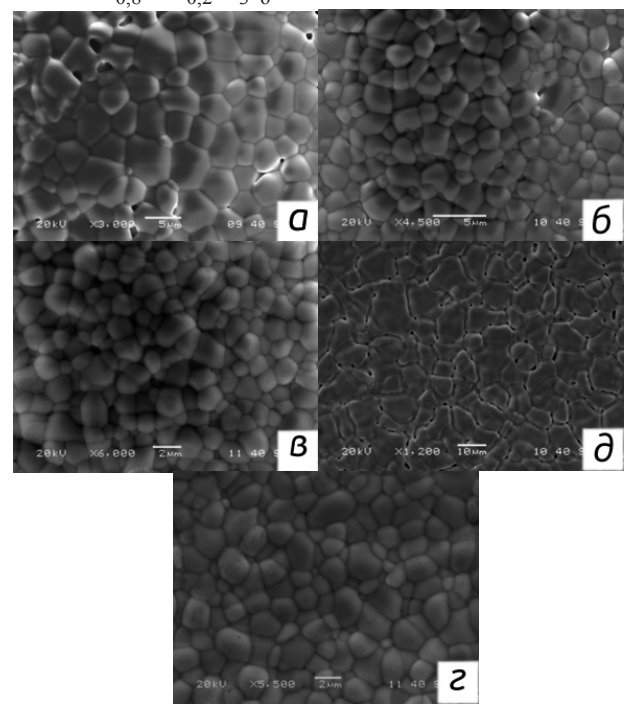

Рис. 3. Микрофотографии поверхности

$$
\begin{gathered}
(1-x) \mathrm{Ce}_{0,8} \mathrm{Nd}_{0,2} \mathrm{O}_{2}-x \mathrm{BaCe}_{0,8} \mathrm{Nd}_{0,2} \mathrm{O}_{3-\delta}: \\
a-x=0, \sigma-x=0,25,6-x=0,5, \\
2-x=0,75, \partial-x=1
\end{gathered}
$$


[1]. В первом случае более низкую проводимость композитных материалов по сравнению с базовыми $\mathrm{Ce}_{0,8} \mathrm{Y}_{0,2} \mathrm{O}_{2-\delta}$ и $x \mathrm{BaCe}_{0,7} \mathrm{Zr}_{0,1} \mathrm{Y}_{0,2} \mathrm{O}_{3-\delta}$ авторы связывают с появлением плохопроводящих фаз на основе $\mathrm{Ba}_{2} \mathrm{YZrO}_{6}$ и $\mathrm{Ba}_{2} \mathrm{ZrO}_{4}$, которые, по-видимому, локализуются на границах зерен и лимитируют процесс электропереноса [4]. Во втором случае низкая проводимость композитов по сравнению с $\mathrm{Ce}_{0,8} \mathrm{Gd}_{0,2} \mathrm{O}_{2-\delta}$ и $\mathrm{BaCe}_{0.8} \mathrm{Gd}_{0,2} \mathrm{O}_{3-\delta}$ связана с высоким контактным сопротивлением границы раздела фаз [1], что может реализовываться и в нашем случае. Высокое контактное сопротивление на границе двух зерен различного сорта непременно должно приводить к увеличению энергии активации общей проводимости композитов (вставка на рис. 4). Отметим, что максимальный Еа имеет образец c $x=0,5$, который в тоже время обладает наименьшей проводимостью в $(1-x) \mathrm{Ce}_{0,8} \mathrm{Nd}_{0,2} \mathrm{O}_{2-\delta}-x \mathrm{BaCe}_{0,8} \mathrm{Nd}_{0,2} \mathrm{O}_{3-\delta}$. Таким образом, концентрационная зависимость энергии активации в композитной системе с ростом перовскитной фазы проходит через максимум. По

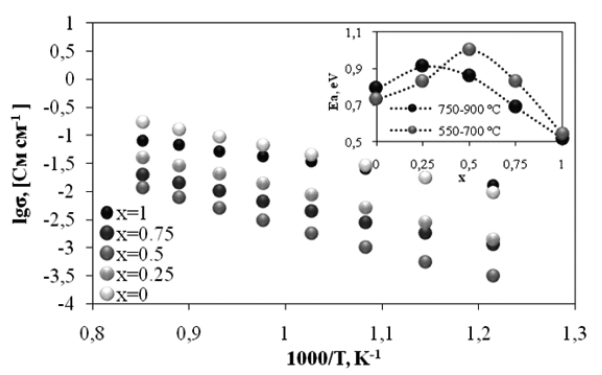

Рис. 4. Температурные зависимости проводимости керамики (1- $x) \mathrm{Ce}_{0,8} \mathrm{Nd}_{0,2} \mathrm{O}_{2-\delta}$ $\mathrm{xBaCe}_{0,8} \mathrm{Nd}_{0,2} \mathrm{O}_{3-\delta}$ во влажном воздухе. Вставка: концентрационные зависимости энергии активации проводимости в низкои высокотемпературном интервалах уровню энергии активации в низкои высокотемпературных интервалах образец с $x=0,25$ сходен с $\mathrm{Ce}_{0,8} \mathrm{Nd}_{0,2} \mathrm{O}_{2-\delta}$. Это может указывать на то, что проводимость данного материала контролируется преимущественно флюоритной фазой. Для композитов с $x=0,5$ и 0,75 , по-видимому, проводимость контролируется перовскитной фазой. Уменьшение размеров зерен керамики (или увеличение их удельной площади контакта) может также рассматриваться причиной снижения общей проводимости композитных систем.

Проводимость материалов также была исследована в зависимости от парцаильного давления кислорода $\left(\mathrm{pO}_{2}\right)$ при $600,700,800$ и $900{ }^{\circ} \mathrm{C}$. Полученные зависимости были обработаны с помощью эмперического уравнения $\sigma_{\text {total }}=\sigma_{e, o} \cdot\left(\mathrm{pO}_{2}\right)^{-1 / 4}+\sigma_{\text {ion,o }}+\sigma_{p, o} \cdot\left(\mathrm{pO}_{2}\right)^{1 / 4}$, где $\sigma_{\text {total }}-$ общая проводимость,

$\sigma_{\text {ion,o }}-$ ионная проводимость (const),

$\sigma_{p, o}-$ дырочная проводимость при $\mathrm{pO}_{2}=1$ атм. Результаты анализа представлены в виде конценрационных зависимостей парциальных проводимостей (рис. 5).

Концентрационные зависимости ионной проводимости при $600-900{ }^{\circ} \mathrm{C}$ (рис. 5a) соответствует представленным выше данным (рис. 4). Сопоставление Еа ионной и общей проводимости (рис. 4) свидетельствует о преимущественно ионном типе проводимости как для композитных материалов, так и для базовых систем.

Электронная проводимость уменьшается с ростом содержания перовскитной фазы в системе $(1-x)$ $\mathrm{Ce}_{0,8} \mathrm{Nd}_{0,2} \mathrm{O}_{2-\delta}-x \mathrm{BaCe}_{0,8} \mathrm{Nd}_{0,2} \mathrm{O}_{3-\delta}$ до $x=$ 0,5 (рис. 6б). Для образцов с $x=0,75$ и 1 электронная проводимость, согла- 
сно проведенному анализу, составляет менее $1 \%$ от общей. Дырочная проводимость проявляется для образцов с $0,5 \leq \mathrm{x} \leq 1$ и увеличивается с ростом $x$ (рис. 5в). Энергии активации дырочной и электронной проводимости для системы «перовскит - флюорит», как правило, выше, чем для базовых оксидов $\mathrm{Ce}_{0,8} \mathrm{Nd}_{0,2} \mathrm{O}_{2-\delta}$ и $\mathrm{BaCe}_{0,8} \mathrm{Nd}_{0,2} \mathrm{O}_{3-\delta}$, что подтверждает явление блокирования

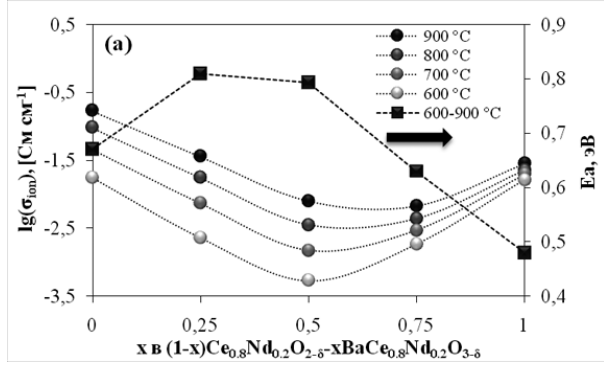

$a$

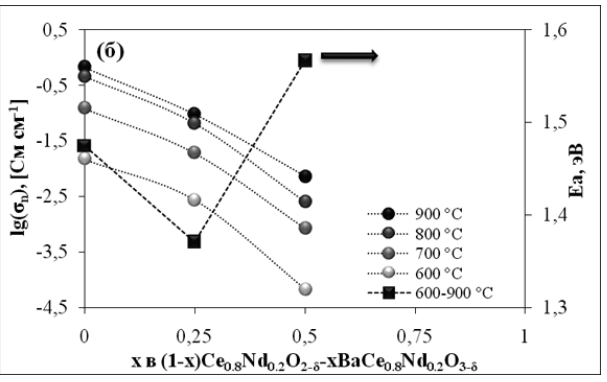

6

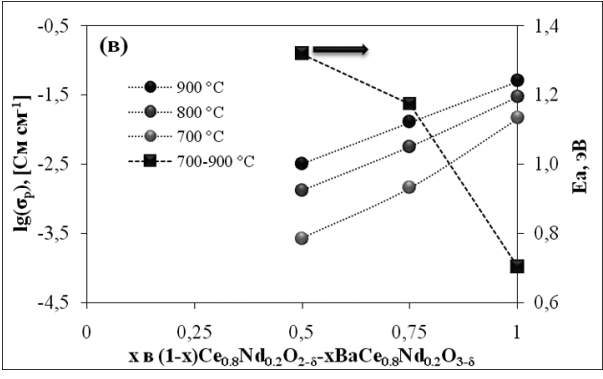

B

Рис. 5. Концентрационные зависимости ионной $(a)$, электронной (б) и дырочной

(в) проводимости и их энергии активации для керамики (1-x) $\mathrm{Ce}_{0,8} \mathrm{Nd}_{0,2} \mathrm{O}_{2-\delta}-$ $x \mathrm{BaCe}_{0,8} \mathrm{Nd}_{0,2} \mathrm{O}_{3-\delta}$ во влажном воздухе как электронной, так и дырочной проводимости в композитах [1-3].

Несмотря на более низкую ионную проводимость композитов, они показывают лучшую термодинамическую и кинетическую устойчивость в условиях долговременных испытания и редокс-циклах (рис. 6), чем базовые материалы. Было установлено, что после 2 редокс-циклов при $900{ }^{\circ} \mathrm{C}$ проводимость $\mathrm{Ce}_{0,8} \mathrm{Nd}_{0,2} \mathrm{O}_{2-\delta}$ уменьшается на $85 \%$ относительно начального уровня. Возможной причиной резкого падения проводимости является зафиксированные методом РЭМ трещины в керамике, которые появляются вследствие частичного восстановления/окисления ионов церия (рис. 7). Изменение степени окисления церия сопровождается

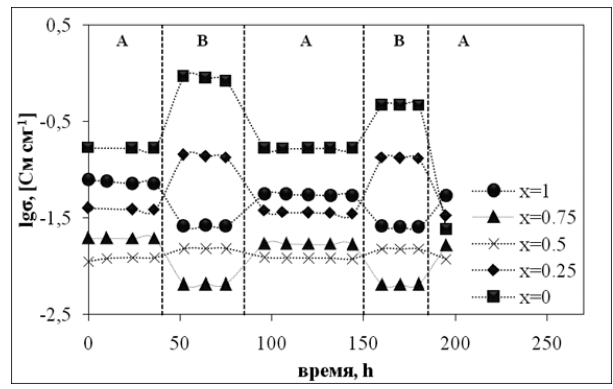

Рис. 6. Временная зависимость проводимости материалов $(1-x)$

$\mathrm{Ce}_{0,8} \mathrm{Nd}_{0,2} \mathrm{O}_{2-\delta}-x \mathrm{BaCe}_{0,8} \mathrm{Nd}_{0,2} \mathrm{O}_{3-\delta}$ при $900{ }^{\circ} \mathrm{C}$.

А соответствует атмосфере c $\mathrm{pO}_{2}=0,21$ aтм, $\mathrm{B}-\mathrm{PO}_{2}=1 \cdot 10^{-18}$ aтм

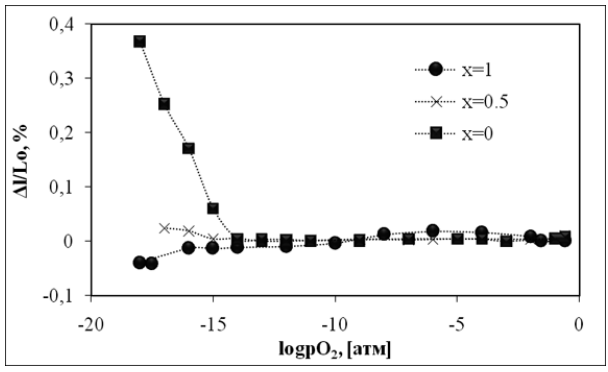

Рис. 7. Химическое расширение керамических материалов $(1-x)$ $\mathrm{Ce}_{0,8} \mathrm{Nd}_{0,2} \mathrm{O}_{2-\delta}-x \mathrm{BaCe}_{0.8} \mathrm{Nd}_{0,2} \mathrm{O}_{3-\delta}$ при $900{ }^{\circ} \mathrm{C}$ 
колебаниями размера кристаллической решетки, поэтому многократное повторение редокс-циклов приводит к механической нестабильности керамики. Для материала $\mathrm{BaCe}_{0,8} \mathrm{Nd}_{0,2} \mathrm{O}_{3-\delta}$ проводимость после 2 циклов уменьшается на $30 \%$ относительно начального уровня. Возможно, это связано с локализацией точечных дефектов различных типов на границах зерен. В процессе нескольких редокс-циклов происходит образование трехмерных дефектов (микротрещин) вдоль границ зерен вследствие скопления и взаимодействия точечных дефектов. Деградация композитных материалов в терминах проводимости не превышает $15 \%$. Согласно РЭМ этих керамических образцов, на поверхности фиксируются локальные поры, которые приводят к несущественному уменьшению проводимости.

\section{Заключение}

В настоящей работе получены новые композитные материалы на основе оксида церия и церата бария цитратнитратным методом, а также изучены их транспортные свойства. Общая проводимость композитных электролитов во влажном воздухе ниже, чем для базовых материалов вследствие высокого межфазного сопротивления и удельной площади контакта зерен. Концентрационная зависимость энергии активации проводимости для

$(1-x) \mathrm{Ce}_{0,8} \mathrm{Nd}_{0,2} \mathrm{O}_{2-\delta}-x \mathrm{BaCe}_{0,8} \mathrm{Nd}_{0,2} \mathrm{O}_{3-\delta}$ имеет минимум при $x=0,5$. Несмотря на более низкую проводимость композитной керамики, они характеризуются малыми вкладами электронных составляющих (проводимоть $n$ - и $p$-типа), а также лучшей термодинамической и кинетической устойчивостью, что позволяет считать такие материалы перспективными электролитами для IT-SOFC.

\section{Экспериментальная часть}

Материалы состава (1-x) свойства материалов были изучены $\mathrm{Ce}_{0.8} \mathrm{Nd}_{0.2} \mathrm{O}_{2-\delta}-x \mathrm{BaCe}_{0.8} \mathrm{Nd}_{0,2} \mathrm{O}_{3-\delta}(x=0 ; \quad$ PФA (DMAX-2500 RIGAKU) и РЭМ 0,$25 ; 0,5 ; 0,75$ и 1 ) были получены по (JSM-5900 LV) соответственно. Процитрат-нитратной технологии, осо- водимость материалов исследовали бенности которой представлены в [3]. 4-зондовым методом на постоянном Порошки требуемого состава син- токе в широких интервалах температур тезировали и спекали на основании $\left(550-900{ }^{\circ} \mathrm{C}\right)$ и парциальных давлений данных ТГ-ДСК анализа и дилатоме- кислорода $\left(10^{-23}-0,21\right.$ атм) с помощью трии при и $1500{ }^{\circ} \mathrm{C}$, соответственно. регулятора Zirconia-318 [5].

Кристаллические, микроструктурные

1. Venkatasubramanian A., Gopalan P., Prasanna T. R. S. // International Journal of Hydrogen Energy. 2010. V. 35. P. 4597.

2. Sun W., Jiang Y., Wang Y., Fang S., Zhu Z., Liu W. // Journal of Power Sources. 2011. 
V. 196. P. 62.

3. Medvedev D., Maragou V., Pikalova E., Demin A., Tsiakaras P. // Journal of Power Sources. 2013. V. 221. P. 217.

4. Huang J., Zhang L., Wang C., Zhang P. // International Journal of Hydrogen Energy. 2012. V. 37. P. 13044.

5. http://zirconiaproject.wordpress.com/ devices/zirconia-318/. 